\title{
Induced Auto-Regeneration with Adipose Tissue in Humans - Beyond Frontiers of Healing
}

\author{
Marco Aurelio Pellon* \\ Plastic Surgeon, Department of Regenerative Medicine Treatment of Burns and Complex Wounds, Clinica Sao Vicente, Brazil
}

Submission: December 01, 2020; Published: December 17, 2020

*Corresponding author: Marco Aurelio Pellom, Plastic Surgeon, Department of Regenerative Medicine Treatment of Burns and Complex Wounds, Clinica Sao Vicente, Brazil

Keywords: Facial Mobility; Malignant Tumors; Human Tissues; Blastema; Chronic Edema; Adipose Tissue; Stem Cells

\section{Opinion}

The search for regeneration of the face and other structures of the human body has undergone several attempts, based on complex surgical techniques with the use of transplantation of fragments or limbs removed from donors, followed by the administration of immunosuppressive drugs for the rest of the patient's life. The results of these face transplants are far from ideal and the degree of dissatisfaction in these patients is very high, leading to cases of severe depression, treatment abandonment and even suicide. In addition to technical problems such as recovery of facial mobility, transplantation of an external anatomical unit differs greatly from transplantation of an internal organ, as its immune behavior is very different. The skin represents the interface between the internal environment of our body and the external environment, therefore it has a rich defense system specialized in responding to all sorts of invaders, which makes it extremely antigenic. For this reason, the doses of immunosuppressive drugs need to be higher and constantly adjusted. We know that immunosuppressants have several side effects such as the possibility of bacterial, viral or fungal infections, with the risk of sepsis, kidney failure and even an increased incidence of malignant tumors, which adds an additional risk to a previously healthy patient [1-5].

The expectation of the patient with severe facial deformity is resocialization, the recovery of self-esteem, in short, psychosocial well-being. In practice, none of these factors materialize. The transplant has little facial mimicry, chronic edema, and the patient still needs to take several medications daily, living with the perennial prospect of rejection or the possibility of manifesting some side effect to the use of immunosuppressants For all these reasons, I believe that this search has not yet ended and that the path of transplantation should be replaced by that of biomimetic regeneration, through three-dimensional self-regeneration triggered or induced by some biomolecular mediator. If we take into account that there are other vertebrate organisms that have this capacity, such as some fish or amphibians, in particular the Salamander, that manage to perform the complete and perfect self-regeneration of a lost limb and remember that in the fertilization of the human egg, only one cell will give rise to the entire complex structure of our body, we can conclude that there is a way to activate this function in human tissues, we just haven't mastered this knowledge yet. In my way of thinking, as long as we continue on the path of transplants + immunosuppressants, the more we will move away from the chance of achieving this cellular unlocking that will start the self-regenerating process [5-10].

Human cells have 3 differentiation blocking moments. In the formation of the zygote, cells are totipotent, that is, they can differentiate into any human cell. After that, the first block occurs, when the cells become pluripotent and differentiate by leaflets: ectoderm, mesoderm and endoderm, then the second block will occur, when the cells become multipotent, differing only in cells of a specific leaflet, and the third block occurs when the cell becomes differentiated, that is to say unipotent, just reproducing itself. But human cells have the capacity to transdifferentiate and reprogram themselves, as occurs in the female breast, where adipose tissue is transdifferentiated in the mammary gland at 


\section{Juniper Online Journal of Dermatology \& Cosmetics}

puberty and pregnancy, and vice versa after breastfeeding. In the Salamander, the regenerative process begins with the formation of a conglomerate of pluripotent cells called blastema that, controlled by the sympathetic nervous system, are differentiating and walking towards the member that will be newly formed [1019].

It is important to note that the current concepts of adipose derived stem cells (ADSCs) are rudimentary and in many publications do not consider the intercellular crosstalk and the importance of the cellular niche as a micro anatomical metabolic unit, where several cells of the same tissue (including stem cells) complement their cellular and molecular capabilities to achieve a single goal, whether revascularization, regeneration or other. Another consideration to be made is how to control the regenerative mechanism: what form to take and when to stop. These messages are certainly memorized in the nuclear DNA of all our cells, like a map or three-dimensional (holographic?) architectural project. Still far from being a regeneration like that of Salamander, we have been able to obtain very surprising results using the adipose tissue as an inducer of cell trans differentiation in complex wounds, obtaining a regeneration of the lesion with revascularization, epithelial growth, absence of fibrosis and mimicking the aspect prior to injury, which I called "Salamander effect", as you will see in the following examples (Figures 1-3).

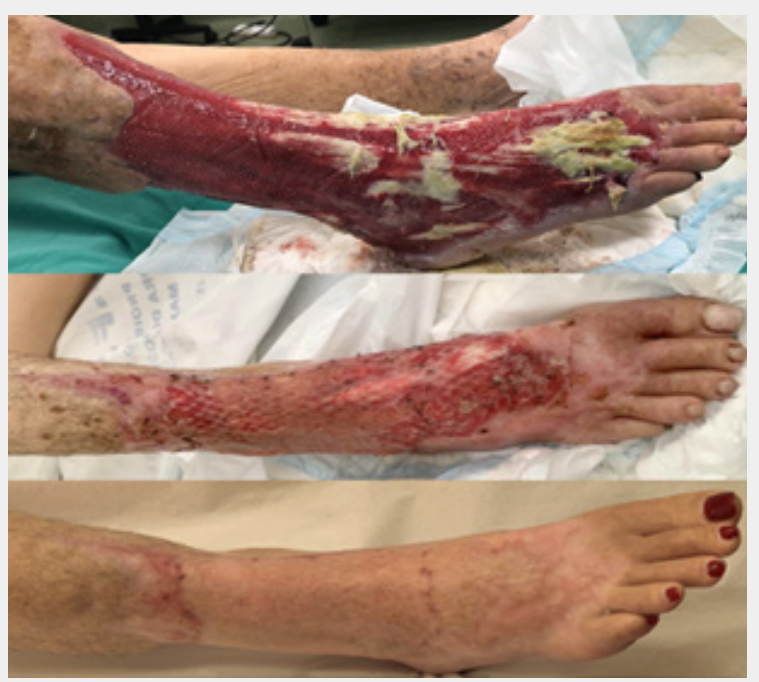

Figure 1: Extensive injury by infection in the foot and right leg in a 72-year-old patient, with loss of skin coverage, and the "salamander effect" obtained after two applications of adipose tissue and a meshed skin graft. The treatment period was 90 days.
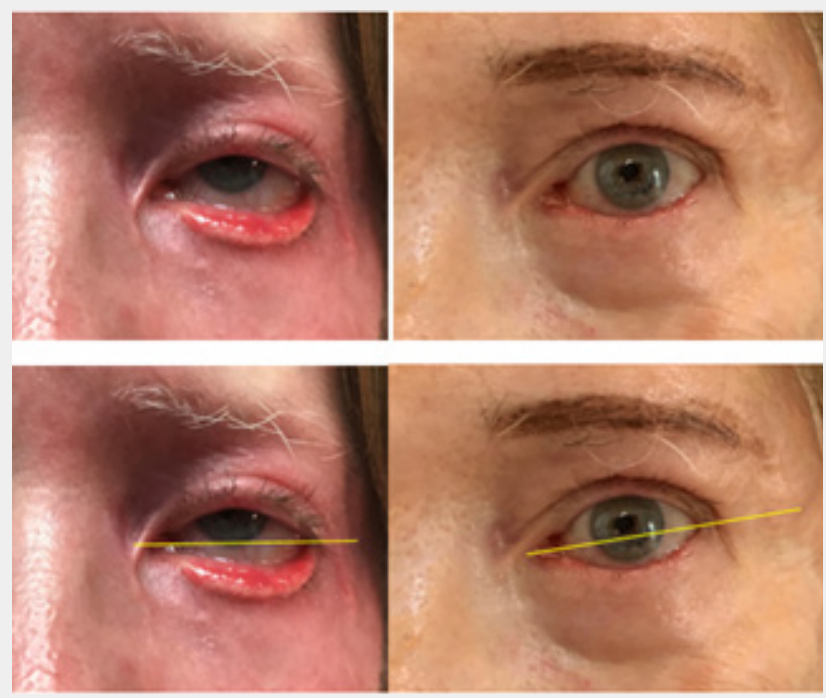

Figure 2: Serious palpebral retraction with cicatricial bridge and eyelid ectropion, secondary to second degree burns on the face and the "salamander effect", after treatment with adipose tissue and total skin graft. Observe the correction of deformities and the repositioning of the palpebral vector. 


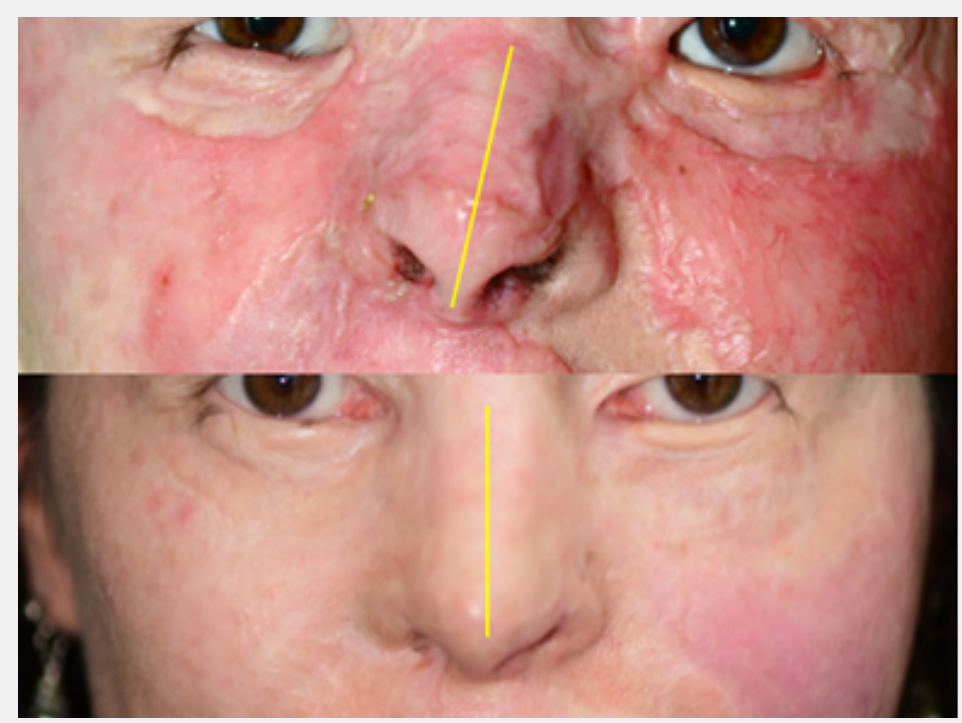

Figure 3: Severe hyperthrophic scars from chemical burn in the face of a 35 year old patient, and the "salamander effect", with fibrosis disappearing and spontaneous repositioning of the nose.

\section{Conclusion}

The use of properly prepared adipose tissue as a modulator of the regeneration of human external lesions shows promising behavior in the desired complete regeneration of a lost limb or fragment.

\section{References}

1. Ryan D, Colin AB, Cheng MC, Fiona W, Valerie H (2014) Defining dermal adipose tissue. Exp Dermatol 23(9): 629-631.

2. Nicole ML, Elisabeth D (2018) The "beginnings" of the neural crest. Developmental Biology 444(suppl 1): S3-S13.

3. Barrett JL, Longaker MT, Peter L (2010) Scarless Fetal Wound Healing: A Basic Science Review. Plast Reconstr Surg 126(4): 1172-1180.

4. Poulos SP, Gary J, Dorothy BH (2010) The development and endocrine functions of adipose tissue. Molecular and Cellular Endocrinology 323(1): 20-34.

5. Lago F, Rodolfo, Juan J, Carlos D, Oreste (2009) Adipokines as novel modulators of lipid metabolism. Review Trends in Biochemical Sciences 34(10): 500-510.

6. Brown NK, Zhou Z, Zhang J, Rong Z, Wu J, et al. (2014) Perivascular Adipose Tissue in Vascular Function and Disease: A Review of Current Research and Animal Models. Arterioscler Thromb Vasc Biol 34(8): 1621-1630.

7. Jernås M, Palming J, Eva J, Levin M, Mats R et al. (2006) Separation of human adipocytes by size: hypertrophic fat cells display distinct gene expression. The FASEB Journal 20(9): 1540-1542.

8. Kreier F, Peter E, Louis M, Thomas C, Ruud M, et al. (2002) Selective parasympathetic innervation of subcutaneous and intra-abdominal fat functional implications. J Clin Invest 110(9): 1243-1250.

9. Romijn JA, Fliers E (2005) Sympathetic and parasympathetic innervation of adipose tissue: metabolic implications. Curr Opin Clin Nutr Metab Care 8(4):440-444.
10. Haochen J, Xiaofan D, Ying C, Huanhuan W, Wenwen Z (2017) Dense Intra-adipose Sympathetic Arborizations Are Essential for ColdInduced Beiging of Mouse White Adipo $\urcorner$ se Tissue. Cell Metabolism 26(4): 686-692.

11. Fonseca AM, Takada J, Vale MI, Lima FB (2006) 0 tecido adiposo como centro regulador do metabolismo. Arq Bras Endocrinol Metab 50(2): 216-229.

12. Schmidt BA, Horsley V (2013) Intradermal adipocytes mediate fibroblast recruitment during skin wound healing. Development 140(7): 1517-1527.

13. Nobuyoshi K, Haruhisa I (2010) Secretory Mechanisms and Intercellular Transfer of MicroRNAs in Living Cells. Journal of Biological Chemistry 285(23): 17442-17452.

14. Müller G (2012) Adipose Tissue-Derived Microvesicles and Exosomes and the Diagnosis of Metabolic Diseases. In: Adipocytes 2013, Nova Science Publishers, USA.

15. Pengyu H, Hao Y, Yue W, Kun L, Tang Z(2019) The Functions and Clinical Application Potential of Exosomes Derived from Adipose Mesenchymal Stem Cells: A Comprehensive Review. Stem Cell Research \& Therapy 10(1): 242.

16. Suga H, Eto H, Aoi N, Jun A, Takuya H, et al. (2010) Adipose tissue remodeling under ischemia: death of adipocytes and activation of stem/progenitor cells. Plast Rec Surg 126(6): 1911-1923.

17. Allyson JM, Ben Z (2016) Adult Cell Plasticity in Vivo: Transdifferentiation is Back in Style. Nat Rev Mol Cell Biol 17(7): 413-425.

18. Cristina E, Nuria M, Anna V, Juan C (2013) Dedifferentiation, Transdifferentiation, and Reprogramming: Future Directions in Regenerative Medicine. Semin Repord Med 31(1): 82-94.

19. Catherine DM, David MG (2013) Positional Information Is Reprogrammed in Blastema Cells of the Regenerating Limb of the Axolotl (Ambystoma mexicanum). PLOS ONE 8(9): e77064. 
(c) (1)

This work is licensed under Creative

Commons Attribution 4.0 License

DOI: 10.19080/JOJDC.2020.03.555616
Your next submission with Juniper Publishers will reach you the below assets

- Quality Editorial service

- Swift Peer Review

- Reprints availability

- E-prints Service

- Manuscript Podcast for convenient understanding

- Global attainment for your research

- Manuscript accessibility in different formats

( Pdf, E-pub, Full Text, Audio)

- Unceasing customer service

Track the below URL for one-step submission https://juniperpublishers.com/online-submission.php 